\title{
Relacja dziecko-rodzic w perspektywie gry komputerowej. Wyniki badania nad obecnością gier wideo $\mathrm{w}$ rodzinie
}

\begin{abstract}
Video games are an important part of contemporary culture and economy, since the number of video game users is constantly increasing, part of that group consists of children. Socialization of young gamers largely takes place in the family. The purpose of this article is to present the conclusions brought by the research on role of video games in the life of the modern family. The study focuses in particular on the issue of technological and cultural competence of children and parents. The research was conducted employing quantitative and qualitative methods - a questionnaire survey and interview. Some worrying phenomena has become noticeable within the pool of twenty four surveyed families, especially in terms of: shortcomings in the cultural and technological competence of parents, insufficient level of parental control, limited communication between parents and children or the lack of support from the school. This article is an attempt to deepen the analysis of impact that video games have on the family environment. The mentioned issue is particularly important in the perspective of growing prevalence of this medium and its specificity - significantly different from older media.
\end{abstract}

1 Damian Gałuszka, Instytut Socjologii, Uniwersytet Jagielloński w Krakowie, Polska, d.a.galuszka@gmail.com. 


\section{Key words:}

modern family, media socialization, video games, generation gap, new media

\section{WSTĘP}

Gry elektroniczne zajmują ważne miejsce we współczesnej przestrzeni społecznej. Stanowią „główny przykład technologii symulacji wchodzącej w sferę kultury popularnej” (Dovey, Kennedy, 2011, s. 16) oraz podstawę dla perspektywicznego sektora światowej gospodarki według danych z raportu The Global Games Market (Heij de, Bosman, Hagoort, Warman, 2013). Stały się one ważnym elementem codzienności wielu osób. Badania pokazują, iż młodzi Polacy (w wieku od 10 do 14 lat) przeznaczają około 50\% wolnego czasu na to medium (średnio 1 godz. i 46 min dziennie) - to więcej niż na czytanie czy zajęcia sportowe (Siwiak, 2014). Gry komputerowe to medium, które przyciąga przed ekrany coraz większą liczbę odbiorców. Od momentu powstania pierwszej gry elektronicznej w kółko i krzyżyk (Mańkowski, 2010) czy Spacewar (Filiciak, 2010) minęło ponad pół wieku, a gry elektroniczne przeszły ogromną transformację. Zmiany nie dotyczą jedynie technologicznych aspektów tego medium, ale także jego statusu kulturowego i pozycji w przestrzeni medialnej. Zmieniająca się rola gier, coraz większe zaangażowanie ludzi w tę formę spędzania czasu oraz osobiste doświadczenia (kiedyś grającego dziecka, a obecnie dorosłego gracza) skierowały moje zainteresowania badawcze w kierunku roli gier elektronicznych we współczesnej rodzinie.

\section{GRY ELEKTRONICZNE}

Swoje rozważania chciałbym rozpocząć od przedstawienia podstawowych dla tego tekstu pojęć, a takim jest z pewnością sama gra wideo. Zdefiniowanie gry komputerowej nie jest łatwe, gdyż jak przekonuje Dominika Urbańska-Galanciak, w przypadku gier komputerowych „mamy do czynienia z terminem nieprecyzyjnym, niewyjaśnionym i niezwykle pojemnym, którego wieloznaczność polega na bogactwie treści i skojarzeń z nim związanych” (Urbańska-Galanciak, 2009, s. 28). Problem definiowania gier cyfrowych w ramach ludologii komplikuje ich zróżnicowanie i wielość aspektów stanowiących podstawę ich opisu. Espen Aarseth - jeden z najznamienitszych badaczy gier (Surdyk, 2009) - określa dziedzinę ich badania jako taką, „w której interdyscyplinarne i empiryczne zróżnicowanie sięga 
ekstremum” (Aarseth, 2010, s. 15). Klasyczną definicją gry jest koncepcja Johana Huizingi (por. Filiciak, 2006), przedstawiona w książce Homo Ludens z roku 1938. Autor prezentuje w niej pogląd, zgodnie z którym „czysta zabawa sama stanowi podstawę i czynnik kultury” (Huizinga, 1985, s. 17). Cała rzeczywistość społeczna ma charakter ludyczny, a zabawa - Huizinga nie odróżnia gry od zabawy - jest pierwotna względem kultury, ale także ją przenika od samego początku. Huizinga (1985, s. 28) określa zabawę jako swobodną czynność, pozostającą poza zwykłym życiem, absorbującą grającego, bezinteresowną i nie dającą korzyści materialnych, a także realizowaną w ramach określonej przestrzeni i w określonym czasie według ustalonych reguł, powołującą do życia związki społeczne, które chętnie otaczają się tajemnicą.

Powyższa definicja nie odnosi się bezpośrednio do współczesnych gier komputerowych, jednak ma ogromne znaczenie dla procesu konstytuowania się ludologii, jej teorii oraz metodologii. Była ona, wraz z sześcioma innymi definicjami gier, przedmiotem analizy duńskiego badacza i projektanta Jespera Juula. Juul chciał stworzyć syntetyczną definicję, „która będzie w stanie wyjaśnić, co łączy gry komputerowe z innymi grami i co dzieje się na granicznych obszarach pola gier” (Juul, 2010, s. 37). Analiza wcześniejszych definicji, ich kategoryzacja i porównanie z wybranymi grami doprowadziły Juula do nowego określenia, które opiera się na sześciu elementach (Juul, 2010, s. 45): regułach gry, zróżnicowanym i policzalnym wyniku, wartościach przypisywanych tym wynikom, wysiłku gracza, przywiązaniu (emocjonalnym) gracza do wyniku oraz negocjowalnych konsekwencjach (ta sama gra może wywierać różny wpływ na świat rzeczywisty).

Użytecznego określenia gry elektronicznej dostarcza wspominany już Aarseth. Twierdzi on, że „gry są facylitatorami, które strukturyzują zachowania gracza i których głównym celem jest przyjemność” (Aarseth, 2007, s. 130).

\section{KLUCZOWE KATEGORIE ANALIZY GIER ELEKTRONICZNYCH}

Gry komputerowe są nowym medium cyfrowym i charakteryzują się określonymi właściwościami. Od momentu pojawienia się pojęcia nowe media w połowie lat 80. XX wieku funkcjonuje ono jako próba zoperacjonalizowania zmian dokonujących się w obszarze mediów pod wpływem nowych technologii (Szpunar, 2012). Warto odwołać się do uznanej charakterystyki mediów cyfrowych autorstwa Lva Manovicha (2006). Przytacza on w cytowanym tekście następujące cechy mediów cyfrowych: reprezentacja numeryczna, modularność, automatyzacja, wariacyjność i transkodowanie kulturowe. W jaki sposób pojęcia te odnoszą się do gier wideo? 
Gry komputerowe mają reprezentację numeryczną, ponieważ są medium przetwarzanym przez urządzenia cyfrowe, projektowanym i programowanym przez ich autorów. Ich struktura jest modularna. Składają się z wielu elementów (np. z silników graficznych, obrazów, dźwięków czy baz danych), które są wytwarzane przez twórców - lub przekształcane przez użytkowników - za pomocą profesjonalnych narzędzi deweloperskich albo narzędzi moderskich (różnego rodzaju edytory). Produkcja gier komputerowych jest częściowo zautomatyzowana. Twórcy mogą usprawniać proces ich produkcji za pomocą różnych narzędzi, a przykładem może być technologia SpeedTree, która umożliwia zaimplementowanie systemu realistycznej roślinności w grach bez konieczności tworzenia go od podstaw. Kolejną cechą nowych mediów jest ich wariacyjność, którą Manovich określa jako istnienie obiektu medialnego w teoretycznie nieskończonej ilości wersji. Taki obiekt nie jest ustalany raz na zawsze i nie musi być powielany jedynie w formie powtarzalnych kopii (Manovich, 2006).

Warto nieco rozszerzyć kategorię wariacyjności. W przypadku gier komputerowych istnieje kilka obszarów, w ramach których przejawia się ich wariacyjność. Gry są wariacyjne w aspekcie rozgrywki, gdyż każde kolejne ich uruchomienie może doprowadzić do powstania innej wersji zmagań. Taka sytuacja ma miejsce przede wszystkim w grach losowych, symulacyjnych, ale także tych, które umożliwiają zmianę niektórych parametrów, na przykład płci czy statystyk głównego bohatera, obszaru (mapy) rozgrywki, warunków środowiskowych itp. Gry elektroniczne są wariacyjne także w aspekcie technologicznym. Często jeden tytuł jest wydawany na różne platformy sprzętowe (komputery osobiste, konsole stacjonarne, a coraz częściej także na smartfony i tablety), co jest źródłem pewnych różnic w wyglądzie danej produkcji, sposobie sterowania czy możliwościach zmiany ustawień. Ostatnią i najważniejszą zdaniem Manovicha (2006) cechą mediów skomputeryzowanych jest ich podział na dwie warstwy: komputerową i kulturową. Warstwa kulturowa składa się z elementów znanych nam z obszaru kultury, takich jak: opowiadanie, fabuła, wątek czy perspektywa. Natomiast warstwę komputerową charakteryzują pojęcia typowe dla języka technicznego, na przykład kategorie: sortowania, kompilowania, kompresowania, funkcji i zmiennej, struktury danych czy specyfikacji technicznej. Obie warstwy wzajemnie na siebie oddziałują, a sposób produkcji, przetwarzania i rozpowszechniania nowych mediów na urządzeniach elektronicznych ma wpływ na ich kształt i może doprowadzać do zmian w warstwie kulturowej. W tym aspekcie gry komputerowe można rozpatrywać jako zbiór plików w warstwie cyfrowej oraz obrazów i tekstów w warstwie kulturowej. Gry cyfrowe to z jednej strony kod maszynowy zrozumiały dla urządzenia, z drugiej natomiast są to obrazy, teksty czy znaczenia odbierane i interpretowane przez gracza. 
Interaktywność jest powszechnie kojarzoną cechą gier komputerowych, a jednocześnie dość mocno krytykowanym pojęciem analitycznym. Według Manovicha „w odniesieniu do mediów komputerowych pojęcie interaktywności jest tautologią [...], nie wnosi nic nowego: jest to po prostu stwierdzenie oczywistego faktu" (Manovich, 2006, s. 128-129). Dlatego też określę je jako taki typ interakcji pomiędzy programem gry a jej użytkownikiem, który umożliwia (poprzez interfejs danej aplikacji) nie tylko biernie odbieranie przekazów, ale także reagowanie na nie i odpowiedź zwrotną gracza. Zdecydowanie lepiej oddaje charakter interakcji pomiędzy grą a odbiorcą pojęcie ergodyczności, zaproponowane przez Aarsetha (2015) w książce Cybertekst. Perspektywy Literatury ergodycznej. Określenie (stanowiące połączenie greckich „ergos” - praca i „hodos” - ścieżka) to odnosi się do zjawiska literatury hipertekstowej i określa taki stosunek między tekstem a czytelnikiem, w którym poza typowym działaniem interpretacyjnym, sam czytelnik musi podjąć działania. Taka interakcja może być określona mianem sprzężenia zwrotnego pomiędzy medium a użytkownikiem. Czytelnik, poprzez wykonywaną pracę i wybór ścieżki, tworzy znaczenia. W przypadku medium ergodycznego nie występuje jeden jasno zdefiniowany tok narracji, ale wiele wariantów opowiadania, które zawierają się w polu zdarzeń konkretnego tytułu.

\section{GRA KOMPUTEROWA W RELACJI DO UŻYTKOWNIKA I W KONTEKŚCIE RODZINNYM}

Postawmy pytanie „kim jest gracz?”. Jak zauważa Katarzyna Prajzner (por. 2012, s. 56), Aarseth odpowiada na to pytanie niejednoznacznie, przytaczając kategorie potencjalnego gracza oraz aktualnego, którym stajemy się w momencie przyswojenia struktury i reguł gry. Podporządkowanie się systemowi gry definiuje gracza, a wchodzenie w tę rolę odbywa się poprzez proces uczenia. Aarseth uznaje niezmienny status ontologiczny gry (jej reguły i struktura nie ulegają zmianie bez względu na to, czy ktoś ją wykorzystuje), która ogranicza podmiotowość gracza, jego swobodę podejmowania decyzji do zakresu dopuszczanego przez strukturę i reguły. Taka deterministyczna wizja biernego gracza, który podąża za instrukcjami gry, nie jest jedyną proponowaną przez Aarsetha. Badacz ten przedstawia też przeciwstawną koncepcję, którą opiera na dwóch pojęciach: gracza implikowanego oraz transgresyjnego - zainteresowanych odsyłam do cytowanego tekstu Prajzner.

Czas na przeniesienie rozważań na szerszy, rodzinny kontekst. W tym miejscu chciałbym przybliżyć termin technizacji, który oznacza „wzajemne relacje tożsamości i kompetencji technologicznej” (Dovey, Kennedy, 2011, s. 82). Autorzy 
Kultury gier komputerowych przekonują, że jest to najważniejsze pojęcie dla zrozumienia współczesnych zjawisk kulturowych, a gusta, zdolności i inklinacje do technologii danej jednostki umożliwiają jej kontakt i rozwijanie relacji z podobnie myślącymi osobami (Dovey, Kennedy, 2011). W pojęciu technizacji zawierają się nawyki związane z używaniem nowoczesnych urządzeń, technologii, a także stosunek do mediów - w tym do gier komputerowych. Jon Dovey i Helen Kennedy określają technizację jako „rodzaj kulturowej hegemonii XXI wieku” (Dovey, Kennedy, 2011, s. 83), który jest poddany dynamicznemu procesowi ścierania się z kulturą popularną, przez co hegemonia technizacji nie jest ostateczna. Odwołując się do postaci hakera i cyborga, a także analizując biografie pionierów branży elektronicznej rozrywki, badacze ci wskazują na paradygmaty technizacji, z których wyłania się postać entuzjasty nowych technologii, cyfrowego tubylcy (por. Prensky, 2001). Można założyć, że kilkuletnie dziecko, uczeń szkoły podstawowej, dorastające w epoce „hegemonii technizacji”, to cyfrowy tubylca, a kim są rodzice? Wydaje się, że w przypadku wielu polskich rodzin linia demarkacyjna pomiędzy cyfrowymi tubylcami a „imigrantami” przebiega w poprzek relacji rodzicielskiej. Po jednej stronie cyfrowej przepaści znajdują się uczniowie szkół, a po drugiej ich rodzice, którzy nie mają dostatecznych umiejętności wykorzystywania nowych technologii, co czyni ich informacyjnymi analfabetami (Szpunar, 2007). Co więcej, Mariusz Przybyła przekonuje, że „przepaść cyfrowa między technologicznie zaawansowaną młodzieżą a częścią nauczycieli jest faktem” (Przybyła, 2012, s. 204), a szkoła nie jest w stanie szybko reagować na dynamiczne zmiany w przestrzeni nowych technologii ze względu na skostniałość swoich struktur (Przybyła, 2012, s. 205). Tak więc dzieci w wieku szkolnym mogą być otoczone cyfrowymi imigrantami nie tylko w przestrzeni domu rodzinnego, ale także w szkole. Technizacja umożliwia wzajemną komunikację pomiędzy podobnie myślącymi osobami. Komunikacja pomiędzy dziećmi a rodzicami wydaje się zakłócona. W badaniu Fundacji Dzieci Niczyje (2013) pojawiły się rozbieżności pomiędzy deklaracjami rodziców i dzieci. 3/4 badanych dzieci przyznało, że używa Internetu u znajomych, a jedynie 1/7 rodziców miała tego świadomość. Może to wskazywać, że część rodziców nie wie, co ich dzieci robią w gronie rówieśników i nie kontroluje tego, jak wykorzystują Internet i nowe media (w tym gry) w trakcie spotkań towarzyskich. Niekorzystną sytuację rodziców względem dzieci ujawniło pytanie o ocenę znajomości komputera. Tylko 6\% dzieci stwierdziło, że zdecydowanie gorzej radzi sobie z komputerem niż rodzice, a 62\% lepiej ocenia swoje umiejętności korzystania z komputera niż umiejętności rodziców. Aż 2/3 badanych przyznało, że zdarza im się pomagać rodzicom w obsłudze komputera. Co ważne, niektóre z badanych dzieci rozpoczęły swoją przygodę z komputerem już w wieku kilku lat. 
Marcin M. Drews przywołuje podział na dwa rodzaje społeczeństw: przemysłowe (pokolenie rodziców, nauczycieli) i informacyjne (pokolenie studentów i uczniów) oraz zarzuca starszemu pokoleniu nieudolność w informatyzacji młodych członków społeczeństwa informacyjnego, przez co muszą oni informatyzować się sami często poprzez zaspokajanie niezdrowej ciekawości i rozrywkę, a nie rzetelną edukację (Drews, 2008). W podobnym tonie wypowiada się Marta Wrońska (2013), pisząc o samodzielnym i absorbującym kontakcie dziecka z przestrzenią medialną, którą z kolei określa jako ważny i naturalny dla dziecka obszar życia społecznego, podlegający ciągłej zmianie, wywołanej przez intensywny rozwój mediów i pozbawiony kontroli ze strony dorosłych.

\section{PROBLEMATYKA BADAWCZA}

Zadając sobie pytanie o możliwość zbadania rodzinnego aspektu² gier wideo, doszedłem do wniosku, iż będzie to możliwe poprzez rozpoznanie i opisanie tych relacji pomiędzy rodzicem a dzieckiem, których elementem są gry komputerowe. Rodzina to „system złożony, w którym wszystkie elementy są ze sobą powiązane i wzajemnie na siebie oddziałują” (Slany, 2008, s. 103). Pełni ona wiele funkcji i stanowi podłoże „wielu wewnątrzrodzinnych zjawisk o psychospołecznym, psychologicznym czy pedagogicznym charakterze” (Tyszka, 1997, s. 698). Oto kilka szczegółowych pytań badawczych:

- Jak można scharakteryzować grające w gry elektroniczne dzieci żyjące w badanych rodzinach?

- Jaki jest poziom wiedzy rodziców na temat medium gier komputerowych?

- W jaki sposób gry komputerowe są obecne w aktach komunikacji werbalnej pomiędzy dzieckiem a rodzicem?

- Jaką rolę odgrywają gry komputerowe w życiu danej rodziny?

- Czy problematyka grających dzieci wykracza poza kontekst rodzinny?

Chciałbym pogłębić dwie kwestie. Pierwsza z nich dotyczy aktualnego stanu kultury, a druga stanu badań nad poruszaną problematyką. Jak wiadomo, Margaret Mead (2000) zaproponowała trójstopniowy podział kultury na kulturę: postfiguratywną, w której dzieci uczą się głównie od swoich rodziców, kofiguratywną, w której dzieci i rodzice uczą się od swoich rówieśników, oraz prefiguratywną, w ramach której dorośli uczą się także od swoich dzieci. Wieloletnie doświadcze-

2 Mowa tu o tradycyjnym w polskim przypadku modelu rodziny i wpływie gier elektronicznych na ich funkcjonowanie. 
nia, a także obserwacje sytuacji w innych rodzinach skłaniają do przekonania, iż w wielu przypadkach to nie rodzice, a grupa rówieśnicza stanowi istotny punkt odniesienia dla dzieci - cecha kultury kofiguratywnej (Mead, 2000) - szczególnie w kontekście użytkowania gier wideo. Mead twierdzi, że kofiguracja jest efektem rozpadu systemu postfiguratywnego, a jedną z przyczyn tego typu zmiany może być pojawienie się nowych technologii, które nie są łatwo przyswajalne dla starszego pokolenia (Mead, 2000). Ten rodzaj wyjaśnienia dość dobrze koresponduje z moimi doświadczeniami i kieruje myśli w kierunku hipotezy opóźnienia kulturowego autorstwa Williama Ogburna (Krzysztofek, 2012). Szybkie przemiany kulturowe o podłożu technologicznym przynoszą nowinki techniczne, a także nowe formy spędzania wolnego czasu (gry elektroniczne). Pomimo podobieństwa do tradycyjnych gier gry komputerowe stanowią, jak pisałem, nową jakość i wymagają pewnego zasobu nowych kompetencji kulturowych, których zdobycie wiąże się z koniecznością podjęcia wysiłku - nie wszyscy rodzice są w stanie (z różnych przyczyn) go podjąć. Obserwowaną przepaść generacyjną w kontekście obsługi gier elektronicznych można niwelować poprzez dialog dzieci i rodziców. Jednak zdaniem Mead (2000) jego powodzenie jest uzależnione od uświadomienia sobie różnic w wykorzystywanych przez młodych i starych językach. Tylko świadomość różnic znaczeniowych czy doświadczeń partnera pozwala na owocne słuchanie, rozumienie i zadawanie pytań. W takim momencie bierze początek kultura prefiguratywna, w ramach której „dzieci, a nie ich rodzice czy dziadkowie, będą reprezentować to, co nastąpi” (Mead, 2000, s. 122).

Przegląd nowej literatury przedmiotu wskazuje, że prowadzi się analizy różnych aspektów istnienia medium gry elektronicznej, w tym związanych z dziećmi czy kontekstem rodzinnym. Jednak można zauważyć pewne braki w interesującej mnie tu dziedzinie. Przykładem mogą być badania Video gamers in Europe 2010 (Interactive Software Federation of Europe, 2010) bądź polski raport Game Industry Trends Kids (NoNoobs) opublikowany w 2014 roku. Z racji charakteru tych analiz (standaryzowane badania ilościowe, technika ankiety) trudno w obu przypadkach mówić o pogłębionej analizie zjawiska. Podstawowe kwestie, takie jak zagadnienie wspólnego grania rodzica z dzieckiem, nie są uszczegółowione ze względu na częstość tej aktywności. Natomiast niezwykle istotne zagadnienia kompetencji kulturowych rodziców, znajomości terminologii związanej ze światem gier elektronicznych czy ich praktycznych umiejętności wykorzystywania nowoczesnych urządzeń są zredukowane do pytań zamkniętych o ograniczonej kafeterii. 


\section{METODOLOGIA BADANIA}

Podstawowym celem mojego badania było uzyskanie pogłębionej wiedzy o zjawiskach zachodzących w badanych rodzinach. Udzielenie zadowalającej odpowiedzi na powyższe pytania badawcze nie byłoby możliwe bez przeprowadzenia badań jakościowych wpisanych w perspektywę interakcjonizmu symbolicznego. Powodów takiej decyzji jest kilka: mikrospołeczny charakter obszaru badawczego, zogniskowanie na kategorię interakcji społecznych, zainteresowanie rolą komunikowania się w relacjach międzyludzkich (Babbie, 2003). Wybór takiej perspektywy teoretycznej pociąga za sobą możliwość odwoływania się do użytecznych pojęć, takich jak potencjał relacyjny, na który składają się: posiadane wyobrażenia, system znaczeń, schematy interpretacyjne oraz opisy ról (Pawłowska, 2006) - będące podstawą nadającą kształt relacjom pomiędzy członkami rodziny. Badanie zostało podzielone na dwie części:

- Część I: wywiady swobodne o charakterze eksploracyjnym z rodzicami,

- Część II: anonimowa ankieta, wypełniana samodzielnie przez dziecko.

W badaniach nad rodziną (Tyszka, 1997, s. 698) często zaleca się łączenie analizy ilościowej z jakościową - czyli sugeruje się zastosowanie triangulacji metod badawczych (Silverman, 2008). I ja ją zastosowałem. Wykorzystana w badaniu technika ankiety ma charakter pomocniczy i nie zmienia jakościowego charakteru omawianego projektu badawczego. Jak przekonuje Krzysztof Konecki, wywiady jakościowe „pozwalają bezpośrednio dotrzeć do epizodów interakcyjnych, zdarzeń, procesów pracy, wypowiedzi o doświadczeniach życiowych [...]” (Konecki, 2000, s. 144). W przedstawianym badaniu wykorzystałem technikę wywiadu swobodnego ze standaryzowaną listą poszukiwanych informacji. Użyłem też ankiety dla dzieci, składającej się z 20 pytań: otwartych, półotwartych, zamkniętych. Przeprowadzone ankiety umożliwiły mi analizę porównawczą deklaracji dzieci i ich rodziców.

Badanie było realizowane na obszarze województwa podkarpackiego (miasto Krosno oraz gmina Wojaszówka) i odbyło się wiosną 2014 roku. Dobór uczestników miał charakter celowy i był podporządkowany przedmiotowi badania. Poszukiwałem takich osób, które mają grające w gry elektroniczne dzieci, co w praktyce oznacza wykorzystanie metody kuli śnieżnej (Dobrodziej, 2015). W trakcie etapu terenowego zrealizowałem 24 rozmowy o zróżnicowanej długości. Przeprowadziłem też 31 (23 chłopców i 8 dziewczynek) ankiet z dziećmi. Średnia wieku przebadanych dzieci wyniosła 11 lat, a zdecydowana większość to osoby uczęszczające do klas IV-VI szkoły podstawowej. Wybór takiego przedziału wiekowego (szkoła podstawowa) był motywowany chęcią zbadania interakcji pomiędzy dziećmi a ich rodzicami w takim okresie życia, w którym władza ro- 
dzicielska i możliwość jej egzekwowania są stosunkowo duże. Dodatkowym czynnikiem jest decydująca rola wczesnego dzieciństwa w procesie socjalizacji jednostki.

Proces analizy danych wywołanych został oparty na schemacie badawczym zaproponowanym przez Kathy Charmaz (por. 2009, s. 19).

„Podstawowa zasada etyczna gromadzenia danych mówi, że badanie nie może narazić respondenta na jakikolwiek szwank”, pisze Bram Oppenheim (2004, s. 103). Zasada ta towarzyszyła mi przez cały okres badań terenowych, co oznacza: przekazywanie uczestnikom badania niezbędnych informacji, uzyskiwanie pisemnej zgody od rodziców na badanie dziecka czy zachowanie wszelkich praw uczestników badania (anonimowości, poufności, odmowy udzielenia wywiadu).

\section{DZIECI, RODZICE I GRY WIDEO - KRÓTKA ANALIZA PORÓWNAWCZA}

Omówienie wyników przeprowadzonego badania chcę rozpocząć od krótkiej analizy porównawczej deklaracji dzieci i rodziców. Dla ankietowanych dzieci komputer jest stałym elementem ich codzienności. Wykorzystują ten sprzęt prawie codziennie, a całkiem duża grupa (około 40\%) w wymiarze kilku godzin dziennie. W przypadku badanych rodziców te proporcje są zdecydowanie inne. Dorośli w dużej mierze unikają nowoczesnych sprzętów, chyba że są one wykorzystywane w celach zawodowych. Tradycyjny pecet nie jest jedynym urządzeniem, na którym dzieci grają w gry elektroniczne. Coraz większe znaczenie odgrywają nowoczesne telefony komórkowe, tablety. Z kolei rodzice w wielu wypadkach nie posiadają odpowiednich kompetencji technologicznych, niezbędnych do obsługi komputera czy innych urządzeń. Zasadniczo wiedza i władza rodziców ograniczają się do dobrze znanych sprzętów, takich jak telewizor. Mali gracze sięgają głównie po tytuły sportowe czy zręcznościowe. Unikają gier bardziej wymagających: symulacyjnych, edukacyjnych, logicznych czy fabularnych. Niestety, część wykorzystywanych gier jest przeznaczona tylko dla dorosłych odbiorców. W odpowiedziach dzieci pojawiały się takie tytuły, jak: Grand Theft Auto, Call of Duty, Counter Strike, Saints Row, Contract Wars, Postal czy Medal of Honor ${ }^{3}$. Dziewczynki raczej stronią od gier pełnych przemocy czy brutalnych obrazów, natomiast chłopcy wprost przeciwnie. Rodzice, jeśli już mają okazję zagrać, wolą

3 Wszystkie te tytuły to gry skierowane tylko i wyłącznie do dorosłych odbiorców. Są one oznaczone kategorią wiekową „,+18” - zgodnie z PEGI, czyli Ogólnoeuropejskim Systemem Klasyfikacji Gier. 
gry proste, niewymagające szczególnych umiejętności manualnych czy wiedzy na temat zasad rozgrywki (chodzi o takie tytuły jak Mario, Pasjans czy też gry mobilne lub społecznościowe). W przypadku niewielkiej części badanych rodzic i dziecko wybierają podobne gry. Wspólne granie dziecka i rodzica jest aktywnością podejmowaną bardzo rzadko. Jeśli już dochodzi do takiej sytuacji, to głównie na prośbę dziecka. Większość rodziców nie interesuje się grami wideo, stawia opory przed zaangażowaniem się w to hobby dziecka. Z kolei dzieci z czasem zaprzestają prób zainteresowania rodziców. Prawie 2/3 wszystkich gier, które pojawiają się w badanych rodzinach, może być wyłączone spod właściwej kontroli ze strony rodziców, ponieważ ich źródłem pochodzenia jest Internet (ściągają głównie chłopcy) oraz rówieśnicy badanych dzieci. Z przeprowadzonych rozmów z rodzicami wynika, że ich zdolność do kontroli internetowych czy koleżeńskich źródeł gier jest niewielka. Niepokojącą obserwacją, która nie jest niczym zaskakującym w świetle wykorzystywanych przez badane dzieci gier, jest dość częsty kontakt ankietowanych z przemocą i brutalnymi obrazami. Prawie połowa badanych dzieci natrafiła na tego rodzaju treści w grach wideo. Nieco rzadziej niepełnoletni gracze czuli strach podczas zabawy, a ponad 1/4 zetknęła się z wulgarnym językiem.

\section{POTENCJAŁ RELACYJNY RODZICÓW - OMÓWIENIE}

Po przedstawieniu ogólnych wniosków chciałbym przejść do pogłębionej analizy najważniejszych aspektów realizowanego projektu. Rozpocznę od poziomu wiedzy i umiejętności rodziców w kontekście poruszanej problematyki. Już na wstępie można zacytować wypowiedź Rozmówczyni A (wyjaśnienia kodów dostępne na końcu tekstu), która przyznała, że „ja się po prostu na tych grach nie znam, w ogóle w to nie wnikam...”. W trakcie badania okazało się, że taka postawa nie jest wyjątkiem, lecz raczej normą, co ma wielorakie przełożenie na relacje rodzica z dzieckiem. Jaki charakter mają braki w zakresie posiadanej przez rodziców wiedzy? Chodzi przede wszystkim o poważne trudności z wymienianiem tytułów gier, z których korzystają dzieci, czy ogólnikową, opisową znajomość gier (przykładowo: „taka gra, co się klocki lego układa”, zamiast tytułu Minecraft). Mali gracze - wręcz przeciwnie. Potrafią bez problemu wymienić tytuły gier, które wykorzystują, także te w języku angielskim - co sprawia szczególne problemy dorosłym (większość rodziców nie radziła sobie z tym językiem). Najprawdopodobniej wyżej opisane problemy są efektem tego, że opiekunowie poznają gry głównie na drodze przypadkowych obserwacji grających dzieci lub w efekcie okazyjnych rozmów z dziećmi. Z tego wynika charakter wiedzy, jaką posiadali badani rodzice: 
były to głównie domysły, a nie potwierdzone - u dziecka czy samodzielnie - fakty. Powierzchowna wiedza na temat gier wideo jest związana z brakami umiejętności na innych płaszczyznach. Niektórzy rodzicie wprost przyznawali, że umiejętności obsługi komputera podopiecznych są zdecydowanie lepiej rozwinięte niż u nich samych. Dość powszechny jest brak umiejętności przeglądania zawartości komputera i wyszukiwania zainstalowanych gier. Z tym brakiem kompetencji technicznych wiąże się wcześniej wskazany problem z opisową znajomością gier. Niektórzy rodzice mieliby problem nie tylko z przeszukaniem urządzenia, ale także z poprawnym ocenieniem, czy dana aplikacja jest grą wideo (trudność w interpretacji przekazów symbolicznych, np. ikon gier). Z drugiej strony większość dzieci potrafi samodzielnie zadbać o dostęp do gier elektronicznych. Nie jest dla nich problemem pobranie gry z Internetu, jej zainstalowanie i skonfigurowanie, nawet dla zaledwie 8-letniego chłopca. Co więcej, jeżeli w domu jest więcej niż jedno urządzenie, na którym można grać, to dzieci chętnie wykorzystują tego rodzaju alternatywny dostęp do gier wideo. W takiej sytuacji niebezpodstawne jest pytanie o możliwość skutecznej socjalizacji, w tym medialnej, dzieci w ramach badanych rodzin. W związku z wyżej opisanym brakiem umiejętności niekiedy rodzice nie są w stanie stwierdzić, czy dziecko wykonało ich polecenia - na przykład zakazu ponownego uruchamiania danej gry. Rozmówczyni B wspominała:

Nie, to był już drugi raz. Raz właśnie go przyłapałam, kazałam mu skasować całkowicie tę grę i później się zaczęły te wyścigi samochodowe. I w tamtym tygodniu poszłam znowu na górę, nie zdążył, bo miał słuchawki i nie usłyszał, że mama przyszła, no to go przyłapałam znowu na tej samej grze.

\section{KOMUNIKACJA DZIECKO-RODZIC A GRY WIDEO}

Istotnym zagadnieniem jest obecność gier wideo w komunikacji pomiędzy rodzicem a dzieckiem. W ramach codziennej komunikacji rodzice koncentrują się na problemach wychowawczych: przesiadywanie przed ekranem, odwlekanie momentu zakończenia gry, prośby o udostępnienie urządzenia. Wyobrażenia moich rozmówców skupiają się głównie wokół możliwości uzależnienia dziecka od gier wideo i przenoszenia negatywnych zachowań z gier do świata fizycznego. Pojawiły się też obawy o zanik bezpośrednich relacji z rówieśnikami czy spadek znaczenia tradycyjnych zabaw w stosunku do gier wideo. Dlatego rodzice unikają (jak określiła to jedna z rozmówczyń) pozytywnej stymulacji dzieci. Jeżeli już coś mówią o grach, to raczej w negatywnym kontekście. Ostrzegają przed: możliwością 
uzależnienia, agresją, konsekwencjami zdrowotnymi (bóle głowy, pogorszenie wzroku). Ogólnie rzecz biorąc, międzygeneracyjna komunikacja werbalna pomiędzy badanymi ma charakter sytuacyjny, instrumentalny, ograniczony do prostych kodów językowych. Dzieci kierują do rodziców głównie prośby: o uruchomienie urządzenia, pozwolenie na grę czy zakup nowej. Czasem dzieci słownie opisują rodzicom gry, które wykorzystują. Mówią wtedy o wydarzeniach w świecie gry i występujących w nim przedmiotach, ewentualnie wyjaśniają zasady rozgrywki. W przypadku niektórych rozmów mali gracze poszerzają swój kod językowy o zapożyczenia z języka angielskiego czy nazwy własne z gry, co sprawia spore trudności interpretacyjne rodzicom. Z kolei rodzice przede wszystkim wysyłają komunikaty, które wiążą się z ich obowiązkiem wychowywania oraz kontrolowania dzieci. Dominują komunikaty sytuacyjne będące odpowiedzią na wyżej opisane prośby dzieci. Rodzice, podobnie jak druga strona, nie podejmują dłuższych, pogłębionych rozmów, ale głównie ograniczają się do krótkich poleceń. Wyjątek stanowią ci opiekunowie, którzy podzielają zamiłowanie do gier ze swoimi dziećmi. W trakcie analizy materiału badawczego udało mi się zauważyć bardzo istotny schemat komunikacyjny, który nazwałem „kontrolowanym przepływem informacji”. Dobrą ilustracją tego zjawiska jest fragment rozmowy z Rozmówczynią C:

Skąd w ogóle syn czerpie informacje o grach? Ja czerpię od syna tylko na temat tej jednej gry, która jest. Mąż też się tym nie interesuje, więc tylko wie o »FIFIE«, a syn pewnie od rówieśników, pewnie z gazet jakichś sportowych, z Internetu.

Tak więc w kontrolowanym przepływie informacji, „oknem” rodzica na świat wirtualnej rozrywki jest w dużej mierze własne dziecko. Z kolei dziecko będzie czerpać swoją wiedzę z Internetu, od rówieśników i przekazywać rodzicom pewne informacje wedle - w mniejszym lub większym stopniu - własnego uznania.

\section{KONTROLA W BADANYCH RODZINACH}

Rodzina pełni wiele funkcji, a jedną z ważniejszych jest funkcja opiekuńczo-wychowawcza. Dlatego w tym miejscu skupię się głównie na kwestii kontrolowania dostępu dzieci do gier wideo. Oczywiście większość rozmówców przyznała, że ogranicza czas, który dziecko spędza przed ekranem. Wyniki przeprowadzonej ankiety pokazują jednak, że nie we wszystkich rodzinach ta kontrola jest skuteczna. Prawie połowa badanych dzieci spędza przed komputerem co najmniej 
dwie godzinny dziennie. Poza ograniczeniami czasowymi opiekunowie powinni zwracać uwagę na zawartość wykorzystywanych przez dziecko programów. Ten aspekt jest jeszcze bardziej zaniedbywany. Analiza wyników ankiety pokazała, że część dzieci uczestniczy w grach przeznaczonych tylko dla dorosłych. W trakcie rozmów z rodzicami okazało się, że niektórzy dorośli wiedzą o tym i świadomie zezwalają na ich wykorzystywanie przez dziecko. Braki w zakresie posiadanej przez rodzica wiedzy na temat gier wideo, skupianie się tylko na powierzchownych (audio-wizualnych) aspektach, a także ich deprecjonowanie do poziomu niewinnej „zabawki” mogą doprowadzić do sytuacji, w której codzienne kilkugodzinne sesje przy konsoli czy przed komputerem nie są dla rodzica syndromem rodzącego się uzależnienia od gier. Te same czynniki mogą odpowiadać za przyzwalanie na gry, których kategorie wiekowe przewyższają wiek dziecka. Są to przykłady konfliktu roli rodzica. Choć dorośli starają się zapewnić swoim dzieciom warunki do prawidłowego rozwoju oraz rozrywki, to nie radzą sobie z obowiązkiem kontrolowania dostępu do gier. Dowodem takiego stanu rzeczy są stosowane metody ograniczania i kontroli dostępu do gier. Potwierdziła się - wyrażona w ankiecie - opinia dzieci, które w większości twierdziły, że rodzice opierają się na okazyjnym zaglądaniu do pokoju czy zerkaniu zza ramienia na ekran - to sposób stosunkowo łatwy, ale jak się okazuje wysoce nieefektywny. Jeżeli rodzic zauważy coś niepokojącego w danej grze, to czasem pojawia się nakaz jej usunięcia - nie zawsze wykonany. Pochodną obserwacji jest przysłuchiwanie się dziecku w trakcie zabawy. Jednak część dzieci gra we własnych pokojach, także z wykorzystaniem słuchawek, co mocno ogranicza możliwość ich obserwacji czy podsłuchiwania. Opisany sposób kontroli może być złudny. Jedną z cech gier komputerowych jest wspominana wariacyjność technologiczna i w aspekcie rozrywki. W praktyce oznacza to, że w jednym momencie program będzie przypominał wyścigi samochodowe - które nie będą budzić zastrzeżeń rodzica - a chwilę później rozgrywka może się zmienić i polegać na, przykładowo, brutalnym eliminowaniu przeciwników. W zdecydowanej większości badani rodzice unikają takich metod kontroli, które wymagają pewnych kompetencji technologicznych. Zabezpieczanie komputera hasłem, analizowanie historii przeglądarki internetowej czy wykorzystywanie specjalistycznego oprogramowania - są to metody w zasadzie nieobecne w zbadanych grupach.

Badania ankietowe pokazały, że ważnym źródłem informacji na temat gier (a także samych gier) są strony internetowe. Dzieci często z nich korzystają, ale z drugiej strony rodzice praktycznie nie mają wiedzy na temat zawartości tych witryn. Co więcej, dzieci czerpią informacje i gry głównie od swoich znajomych, czyli w ramach swojej grupy rówieśniczej. Z przyczyn oczywistych dorośli są wyłączeni z tego rodzaju komunikacji wewnątrzgrupowej. 


\section{OTOCZENIE SPOŁECZNE RODZINY A GRY WIDEO}

Ostatnie zagadnienie jest próbą wyjścia z analizą w otoczenie społeczne rodziny. W badaniu ankietowym większość dzieci zadeklarowała, że gra również poza domem, głównie u rówieśników. Wyjście małego gracza poza próg własnego domu wiąże się z kilkoma problemami. Jednym z nich jest brak kontroli nad dzieckiem. Rodzice mają tego świadomość i często akceptują taki stan rzeczy. Opiekunowie tłumaczą się albo brakiem możliwości sprawdzania tego, co dzieci robią w innych domach, albo opierają się na zaufaniu do innych rodziców. Ta ufność nie jest jednak podparta silnymi przesłankami, ponieważ w zdecydowanej większości badanych rodzin dorośli nie rozmawiają między sobą na temat gier wideo (np. podczas spotkań towarzyskich). Najczęściej tylko od dobrowolnego przyznania się dziecka zależy możliwość zdobycia przez rodziców informacji na temat jego aktywności w trakcie zabawy poza domem, a często przytaczane tytuły gier nic nie mówią rodzicom.

Do rodziny docierają różne przekazy. Część z nich pochodzi z mediów tradycyjnych, a jednym z ważniejszych jest telewizja. Według najnowszych danych GUS, aż 86\% Polaków w wieku 15 lat i więcej ogląda telewizję lub inne materiały filmowe i przeznacza na nie około 2,5 godziny dziennie (Siwiak, 2014). W trakcie wywiadów okazało się, że zdecydowanie dłuższa obecność tego medium w życiu rodzin stała się podstawą do nabycia przez rodziców pewnych kompetencji wychowawczych, związanych między innymi z ograniczaniem dostępu dzieci do niepożądanych treści (głównie o charakterze erotycznym lub pornograficznym). Opiekunowie zwracają uwagę na ograniczenia wiekowe (w formie znaków w rogu ekranu) w przypadku filmów czy programów telewizyjnych, a w większości przypadków ignorują - lub też nie wiedzą o nich - ograniczenia w grach. Potrafią założyć blokadę rodzicielską w telewizorze, jednak ich umiejętności w zakresie ograniczania dostępu do nowszych urządzeń są niewielkie. Co więcej, kilka razy rozmówca skojarzył określenie „program do kontroli rodzicielskiej” nie z programem komputerowym, ale właśnie blokowaniem kanałów telewizyjnych. Podobnie jest z samodzielnym oglądaniem telewizji przez dziecko. Są rodziny, w których komputer jest umieszczony w pokoju dziecka, a telewizję może ono oglądać tylko w towarzystwie rodziców (wspólny pokój, salon). Granicą nie do przekroczenia dla uczestników badania są sceny z elementami nagości. Sceny erotyczne w filmie zawsze są związane z przełączeniem kanału lub wyproszeniem dziecka. Z drugiej strony większość rodziców akceptuje (poprzez brak realnych działań na rzecz ich wyeliminowania, a nie na płaszczyźnie deklaracji) brutalne obrazy, ekspozycje krwi czy przemocy (zabijanie) w grach wideo. Część opieku- 
nów jest w stanie sprawdzić informacje o wyświetlanym filmie (np. w teletekście czy elektronicznym przewodniku po programach), ale te same osoby z reguły nie przejawiają podobnej inicjatywy w przypadku gier komputerowych. Co więcej, dorośli często interpretują i oceniają gry wideo w sposób właściwy dla mediów tradycyjnych. Ograniczają się tylko i wyłącznie do ich aspektów wizualnych, co mocno spłaszcza perspektywę, szczególnie w przypadku medium tak złożonego jak gry komputerowe. Rodzice powoływali się na umowność przekazu audiowizualnego w grach elektronicznych. Śmierć czy zabijanie ludzi w grach są zdaniem niektórych rozmówców mało „rzeczywiste”, to znaczy wyglądają wprawdzie jakby wszystko się działo „na żywo”, ale nie wygląda to tak drastycznie jak na filmie. Niestety, rodzice nie mieli pojęcia, że gry wideo angażują odbiorcę w sposób zgoła odmienny niż filmy. Warto tutaj przywołać wspomniany już pogląd Aarsetha o definiowaniu gracza przez grę. Dzieci muszą się aktywnie angażować w pewne wydarzenia (np. mordowanie innych postaci), by skutecznie działać w grze, dlatego niektórzy rodzice nie powinni w tak bezrefleksyjny sposób podchodzić do tego medium i ignorować jego wpływ na użytkownika.

W tym miejscu należy wspomnieć o jeszcze jednym często podnoszonym przez rozmówców problemie: braku wsparcie ze strony szkoły. Zdecydowana większość rodziców stwierdziła, że w szkołach nie podejmuje się problematyki związanej z grami, ewentualnie tylko w wyjątkowych sytuacjach, takich jak: nadzwyczajna agresja dziecka czy nadużywanie urządzeń mobilnych na zajęciach. Bardziej świadomi rodzice mają pewne konkretne oczekiwania względem instytucji, gdyż jak powiedział Rozmówca D:

Z chęcią dowiedziałbym się czegoś więcej, na przykład o radach dla rodziców czy wszystkich opiekunów. Jak naprawdę prowadzić tę politykę dostępu dziecka do gier czy do komputera, co jest dobre, a co jest złe. Ja rozumiem, że nikt mi nie poda jakiejś złotej definicji, natomiast parę zasad czy wiedzy w tym zakresie. Powiem, że cieszyłoby się to ogromnym zainteresowaniem, bo sądzę, że to jest teraz bardzo ważne w procesie wychowania dzieci.

\section{PODSUMOWANIE}

Po takim przedstawieniu najważniejszych wniosków z badania nietrudno o analogie do przytaczanych już koncepcji Ogburna oraz Mead. Brak zrównoważonego rozwoju warstwy materialnej i niematerialnej kultury znalazł swoje odzwierciedle- 
nie w codziennych praktykach badanych rodzin. Dostęp do nowoczesnych technologii nie jest utrudniony, a w domach uczestników badania pojawiają się kolejne urządzenia: smartfony, tablety, konsole do gier. Niestety, osoby odpowiedzialne za kształtowanie młodych umysłów, informatyzowanie ich, ukierunkowywanie dziecięcej ciekawości na właściwe obszary przestrzeni nowych mediów, same potrzebują pomocy, ponieważ w większości przypadków żyją one w granicach, które wyznaczyły jakiś czas temu ówczesne media masowe, przede wszystkim telewizja. Obraz aktualnej sytuacji w tych rodzinach wpisuje się w charakterystykę kultury kofiguratywnej Mead. Zarówno dla dorosłych, jak i dzieci najważniejszym źródłem wiedzy społecznej w zakresie mediów są grupy rówieśnicze. Owszem, rodzice decydują o pewnych granicach, w ramach których może odbywać się kształtowanie osobowości dziecka i jego rozwój (w końcu jest to jedna z głównych funkcji rodziny), jednak szybkie przemiany w przestrzeni medialnej, szczególnie mediów cyfrowych, sprawiają, że rodzice wypadają poza obszar zainteresowań i działań dzieci. Taka sytuacja rodzi wiele problemów wychowawczych. Mead uważa, że panaceum może być dialog. Przeprowadzona analiza procesu komunikacji rodziców z dziećmi pokazuje jednak, że tego dialogu w zasadzie nie ma. Dlaczego? Otóż obie strony interakcji społecznej posiadają różne potencjały relacyjne. Ich zasoby wyobrażeń społecznych są źródłem odmiennych wniosków na temat gier wideo, a przypisywane im znaczenia doprowadzają raczej do sytuacji konfliktu, a nie wzajemnego zrozumienia, czego oczekiwałaby Mead. Młodsze pokolenie nie znajdzie w sobie zrozumienia i chęci pomocy dla starszego, jeśli dorośli będą przyjmować tak autorytatywną i pejoratywną postawę wobec zainteresowań dzieci. Badani rodzice raczej podtrzymują asymetryczny charakter swojej relacji z dzieckiem, w którym to rola rodzica ma być nadrzędna wobec roli dziecka. Brakuje prób przełamania tego rodzaju schematów, prób podjęcia roli drugiego gracza, przeciwnika w grze, partnera w zabawie. W takim wypadku trudno oczekiwać, że owo przejście z etapu kultury kofiguratywnej do kultury prefiguratywnej (w ramach której to dzieci mają największe znaczenie i „przeprowadzają” dorosłych do nowego świata po „rewolucji elektronicznej”), oparte w dużej mierze na radykalnym przemodelowaniu relacji łączącej stare i młode pokolenie, jest w ogóle osiągalne. W obliczu opisanych w tym badaniu zjawisk raczej trudno oczekiwać, że dorośli zrezygnują ze swojej dominującej pozycji i - często iluzorycznej - kontroli nad dziećmi.

Jeżeli zmiana sytuacji nie jest możliwa poprzez endogenne przemiany w ramach relacji rodzinnych, to warto zastanowić się nad możliwością zaangażowania szkoły w proces wzbogacania potencjałów relacyjnych rodziców. Niektórzy badani sami zauważyli konieczność wsparcia instytucjonalnego. Rzetelna i obiektywna 
wiedza, odczarowanie wizerunku gier (gry wideo są często przedstawiane jako źródło większości problemów wychowawczych i taka charakterystyka jest często powielana w tradycyjnych mediach), a przede wszystkim poprawa umiejętności praktycznych rodziców - to tylko część zadań, które mogą zostać podjęte przez szkoły. Próby przekazania odpowiednich treści, wsparte autorytetem nauczyciela, pedagoga czy innego eksperta, mogą zachęcić rodziców do większego zaangażowania w hobby dzieci i wzbogacić ich potencjał relacyjny. Co więcej, podjęcie takich działań przez szkoły mogłoby pozytywnie wpłynąć na jakość i skuteczność kontroli rodzicielskiej w wielu rodzinach. Instytucja szkoły powinna zaangażować się w ten proces, ponieważ rodzice zawsze są tymi pierwszymi, znaczącymi innymi.

Niniejszy artykuł stanowi jedynie ogólne przedstawienie skomplikowanego obrazu - będącego efektem przeprowadzonych badań terenowych. Moje badanie miało charakter eksploracyjny. Chciałem naświetlić pewne zjawiska i dać impuls do bardziej pogłębionych analiz. Uważam, że wsparcie dla rodziców powinno mieć charakter zorganizowany, a dobrą formą mogą być warsztaty dla rodziców czy pedagogów szkolnych z zakresu wychowywania grających dzieci. W dokonanej analizie dostrzegam zaczątki programu takich szkoleń.

Wykorzystane wywiady:

A - kobieta, wiek około 35 lat, 4-osobowa rodzina, bardzo dobra sytuacja materialna, dwóch synów w wieku szkolnym, mąż dyrektor.

B - matka 12-letniego chłopca, wiek około 40 lat, 5-osobowa rodzina, przeciętna sytuacja materialna, dzieci w wieku szkolnym, zajmuje się domem, a mąż pracuje fizycznie.

C - matka 13-letniego gracza, wiek około 30 lat, 4-osobowa rodzina, dobra sytuacja materialna, dzieci w wieku szkolnym, rodzice posiadają wykształcenie wyższe, matka jest nauczycielką w szkole podstawowej.

D - mężczyzna, wiek około 45 lat, 5-osobowa rodzina, bardzo dobra sytuacja materialna, dzieci w wieku szkolnym, ojciec pełni funkcję dyrektora, matka na stanowisku kierowniczym.

\section{Literatura:}

Aarseth, E. (2007). I Fought the Law: Transgressive Play and The Implied Player. Pobrane z: http://www.digra.org/wp-content/uploads/digital-library/07313.03489.pdf.

Aarseth, E. (2010). Badanie zabawy: metodologia analizy gier. W: M. Filiciak (red), 
Światy z pikseli. Antologia studiów nad grami komputerowymi (s. 13-36). Warszawa: Wydawnictwo SWPS.

Aarseth, E. (2015). Cybertekst: Perspektywy literatury ergodycznej. Pobrane z: http:// techsty.art.pl/magazyn2/artykuly/aarseth_cybertekst.html.

Babbie, E. (2003). Badania społeczne w praktyce. Warszawa: Wydawnictwo Naukowe PWN.

Charmaz, K. (2009). Teoria ugruntowana. Praktyczny przewodnik po analizie jakościowej. Warszawa: Wydawnictwo Naukowe PWN.

Dobrodziej, P. (2015). Metoda kuli śnieżnej (ang. snowball sampling). Pobrane z: http:// dobrebadania.pl/slownik-badawczy.html?b=baza\&szczegolowo=181.

Dovey, J., Kennedy, H. (2011). Kultura gier komputerowych. Kraków: Wydawnictwo Uniwersytetu Jagiellońskiego.

Drews, M.M. (2008). Gry komputerowe a analfabetyzm funkcjonalny i informacyjny. Homo Communicativus, 2 (4), s. 59-72.

Filiciak, M. (2006). Wirtualny plac zabaw. Gry sieciowe i przemiany kultury współczesnej. Warszawa: Wydawnictwa Akademickie i Profesjonalne.

Filiciak, M. (2010). Światy z pikseli. Antologia studiów nad grami komputerowymi. Warszawa: Wydawnictwo SWPS.

Fundacja Dzieci Niczyje. (2013). Bezpieczeństwo dzieci w internecie 2013. Pobrane z: http://fdn.pl/sites/default/files/file/Raporty_badawcze/Bezpieczenstwo_dzieci_w_internecie_2013.pdf.

Heij de, B., Bosman, S., Hagoort, T., Warman P. (2013). The Global Games Market 2013. Pobrane z : http://www.newzoo.com/wpcontent/uploads/2011/06/Newzoo_Free_Global_Trend_Report_2012_2016_V2.pdf.

Huizinga, J. (1985). Homo ludens. Zabawa jako źródło kultury. Warszawa: Wydawnictwo Czytelnik.

Interactive Software Federation of Europe. (2010). Video gamers in Europe 2010. Pobrane z: http://www.isfe.eu/sites/isfe.eu/files/video_gamers_in_europe_2010.pdf.

Juul, J. (2010). Gra, gracz, świat: w poszukiwaniu sedna „growości”. W: M. Filiciak (red.), Światy z pikseli. Antologia studiów nad grami komputerowymi, (s. 37-60). Warszawa: Wydawnictwo SWPS.

Konecki, K. (2000). Studia z metodologii badań jakościowych. Teoria ugruntowana. Warszawa: Wydawnictwo Naukowe PWN.

Krzysztofek, K. (2012). Zmiana permanentna? Refleksje o zmianie społecznej w epoce technologii cyfrowych. Studia socjologiczne, 4 (207), s. 7-39.

Manovich, L. (2006). Język nowych mediów. Warszawa: Wydawnictwa Akademickie i Profesjonalne.

Mańkowski, P. (2010). Cyfrowe marzenia. Historia gier komputerowych i wideo. Warszawa: Wydawnictwo Trio.

Mead, M. (2000). Kultura i tożsamość. Studium dystansu międzypokoleniowego. Wyd. 2. Warszawa: Wydawnictwo Naukowe PWN.

NoNoobs. (2014). Game Industry Trends Kids. Pobrane z: http://2014.gitkids.pl/raport.

Oppenheim, A.N. (2004). Kwestionariusze, wywiady, pomiary postaw. Poznań: Wydawnictwo Zysk i S-ka. 
Pawłowska, A. (2006). Badanie relacji społecznych w organizacji z wykorzystaniem metod projekcyjnych. Studia i Materiały, 1, s. 7-17.

Prajzner, K. (2012). Gracz, postać, obecność i tożsamość. W: A. Pitrus (red.), Olbrzym w cieniu. Gry wideo w kulturze audiowizualnej (s. 57-66). Kraków: Wydawnictwo Uniwersytetu Jagiellońskiego.

Prensky, M. (2001). Digital Natives, Digital Immigrants. Pobrane z: http://www.marcprensky.com/writing/Prensky\%20-\%20Digital\%20Natives,\%20Digital\%20Immigrants\%20 -\%20Part1.pdf.

Przybyła, M. (2012). Digital natives vs. Digital immigrants. Studia Edukacyjne, 23, s. 203-216.

Silverman, D. (2008). Prowadzenie badań jakościowych. Warszawa: Wydawnictwo Naukowe PWN.

Siwiak, K. (red.). (2014). Badanie budżetu czasu ludności w 2013 r. Pobrane z: http:// stat.gov.pl/download/gfx/portalinformacyjny/pl/defaultaktualnosci/5468/18/1/1/notatka_bc_2013_22_08_ost_2_.pdf.

Slany, K. (2008). Wpływ urodzenia dziecka na relacje małżeńskie i podejmowane przez małżonków role rodzicielskie. Studia Humanistyczne AGH, 6, s. 103-115.

Surdyk, A. (2009). Status naukowy ludologii. Przyczynek do dyskusji. Homo ludens, 1, s. 223-244.

Szpunar, M. (2007). Digital divide, a nowe formy stratyfikacji społecznej w społeczeństwie informacyjnym - próba typologizacji. Pobrano z: http://www.magdalenaszpunar. com/_publikacje/2007/digital_divide.pdf.

Szpunar, M. (2012). Nowe-stare medium. Internet między tworzeniem nowych modeli komunikacyjnych a reprodukowaniem schematów komunikowania masowego. Warszawa: Wydawnictwo IFiS PAN.

Tyszka, Z. (1997). Rodzina. W: W. Pomykało (red.), Encyklopedia pedagogiczna (s. 698). Warszawa: Fundacja Innowacja.

Urbańska-Galanciak, D. (2009). Homo players. Strategie odbioru gier komputerowych. Warszawa: Wydawnictwa Akademickie i Profesjonalne.

Wrońska, M. (2013, wrzesień). Dorastanie w środowisku cyfrowym - od immersji, poprzez bezkrytyczną fascynację, do kultury medialnej. Referat przedstawiony na Ogólnopolskim Sympozjum Naukowym CZŁOWIEK - MEDIA - EDUKACJA, Kraków. Pobrano z: http://www.ktime.up.krakow.pl/symp2013/referaty_2013_10/wronska.pdf. 